\title{
The Effect of Firm Profitability on Expected Stock Return In ASEAN Stock Market
}

\author{
Nathania Clara ${ }^{1}$, Sung Suk kim²* \\ 1,2Department of Management, Universitas Pelita Harapan (UPH), Tangerang, Indonesia \\ *Corresponding Author: sungsuk.kim@uph.edu
}

\begin{abstract}
This research discusses and analyzes the company's profitability related to the company's stock return performance Profitability of the firm is related to the firm's performance of stock return. This study uses time-series data with a total sample of 1,010 firms from five countries in ASEAN (Indonesia, Thailand, Malaysia, Philippines, and Vietnam) from January 2010 to December 2019. Fama-French 3 factor model based on two different profitability showed that profitability positively affects the stock return in ASEAN markets. Fama-MacBeth's (1973) regression confirms that firm profitability scaled by operating profit-to-equity or operating profit-to-assets positively influences expected stock returns in the ASEAN market.
\end{abstract}

Keywords: Profitability; expected stock return; ASEAN stock market

\section{INTRODUCTION}

It has become a common understanding that profitability is one of the instruments of measuring a firm's financial performance. Profitability indicates the ability to create profit over sales, assets, and capital in a certain period (Margaretha \& Supartika, 2016). Profit maximizing becomes a primary objective that must be achieved by a firm for long-term business continuity and facing existing competition. Besides, a profitable firm is considered good for potential investors, which suggests that a firm is capable of providing a higher expected stock return.

Profitability becomes one of the firm's characteristics to predict expected stock returns. In the valuation theory, Ball et al. (2016) and Yin et al. (2020) empirically evidence that profitability tends to have positive effects on stock return. Miller \& Modigliani (1961) argue that firms with higher future earnings result in higher stock returns based on future profitability by controlling for other variables. Bouchaud et al. (2019) relate the profitability anomalies with the sticky expectations of the investors that are too slow to adjust the profitrelated information.

There are several ways to measure profitability until which costs are included in its profitability. Operating profit that excludes the effects of financial leverage and returns on equity that just represents the equity investors' residual claims are wildly used. Hou et al. 
(2015) choose to use return on equity to show the effect of the profitability of the earnings on expected stock return. They find that a higher return on equity produces a greater expected stock return. Ball et al. (2015) show that profitability, as measured by operating profit, tends to stronger effect on expected stock return than gross profit and net income. Whereas, Akbas et al. (2017) find that gross profit has strong power to predict expected stock return.

This study aims to investigate the effect of firm profitability on expected stock return in the ASEAN stock market except for Singapore, Myanmar, and Cambodia, using operating profit as a more comprehensive proxy. We exclude Singapore because it belongs to the developed market and Myanmar and Cambodia with a relatively short history of stock markets. Therefore, this study aims to conduct an empirical study in the ASEAN stock market, which certainly has characteristic differences with the stock market in other regions, such as rapid development of institutional with the regional economic growth. This research is also expected to contribute to similar studies in other developing countries that are still limited.

\section{LITERATURE REVIEW AND HYPOTHESES DEVELOPMENT}

\section{Relationship between Firm Profitability and Expected Stock Return}

In previous studies, there is empirical evidence that profitability is related to expected stock returns. Fama \& French (2015) and Hou et al. (2015) described a positive relationship between the profitability of the firm and expected stock return which is consistent with the valuation theory. Previously Modigliani \& Miller (1961) argue that this positive relationship is based on the future dividend payment. This model assumes that the market value of equity is the sum of the present value of the expected dividend, as following equation 1.

$$
M_{t}=\sum_{\Delta=1}^{\infty} \frac{E\left(Y_{t+\Delta}-d B_{t+\Delta}\right)}{(1+r)^{\Delta}}
$$

where $M_{t}$ is the market value of equity at time $t, Y_{t}$ are earnings for equity at time $t$, $d B_{t+\Delta}$ is change in book value of equity at time $\mathrm{t}$ and $\mathrm{t}+\Delta$, and $\mathrm{r}$ is a long-term discount rate that represent the proper riskiness of expected dividends. This Dividend Discount Model after dividing book value of equity $\left(B_{t}\right)$ of the previous equation, there are three predictions about an expected stock return.

First, by controlling for expected earnings of equity portion and expected changes of the book value of equity, firms that have a bigger value of book-to-market ratio produce a greater expected stock return. Second, by controlling for expected earnings of equity portion and expected changes of the book value of equity due to reinvestment portion of the earnings, firms that have greater expected earnings relative to current book value of equity produce bigger expected stock returns. Third, by controlling for expected earnings for equity portion and expected earnings of equity portion relative to book value of equity, firms that have bigger expected growth in book value of equity due to reinvestment portion of the equity produce a smaller expected stock return.

Hou et al. (2015) show the effect of profitability on expected stock return predicted by the valuation theory. Ball et al. (2016), Akbas et al. (2017), Berggrun et al. (2020), and Yin et al. (2020) use cross-section return regression to explain average stock return with size, 
book-to-market, asset growth, and profitability. When profitability from the previous year is used in the model with asset growth, size, and book-to-market as control variables, it is shown that profitability has a positive effect on the average return and asset growth has a negative effect on average return. Accruals have a negative effect on future returns because accruals and future profitability are negatively related. When the variable size and bookto-market are used, firms have greater profitability produce higher average returns. In comparison, firms with a higher probability of default have lower average returns. Ball et al. $(2015,2016)$ and Yin et al. (2020) use portfolios sorted on the size of the firm and bookto-market ratio. Profitability of the previous year and asset growth as explanatory variables can increase the power of explanation of average return. The conclusion of this test is that profitability has a positive effect on average return.

\section{Relationship between Differences in Profitability Measurement and Expected Stock Return}

A firm that shows historically and currently profitable is assumed to have huge potential of growth in profitability in the future. Hou et al. (2015) document that greater previous ROE tends to produce a more expected stock return. They argue that since the current market price depends on the current cash flow in ceteris paribus, more profitable firms that may produce more cash flow are inclined to produce the higher expected stock return.

Whereas, Novy-Marx (2013) investigates the relationship between gross profit as a new measure of the profitability of the firm and expected stock return. Gross profit is interpreted as the most accurate measurement and reflected the true economic profitability. Using Fama \& MacBeth's (1973) regression, Novy-Marx (2013) shows that profitability measured by gross profit has the same level of power as a book-to-market ratio to account for expected stock return. Akbas et al. (2017) find a positive effect of profitability on expected stock return using gross profit-to-assets as a proxy. Liu \& Yadohisa (2018) and Cakici et al.(2021) also show the same results based on the Japanese stock market.

Ball et al. $(2015,2016)$ proposes an alternative profitability measure to predict expected stock return, i.e., operating profit (gross profit minus SGA expense, excluding R\&D expenditures). Based on the study conducted, operating profit has a stronger relationship with expected stock return than gross profit or net income. Operating profit can significantly explain expected stock return as far as ten years. Recently, Berggrun et al. (2020) investigate the profitability of the firm to expected stock return in Latin America. They show that univariate and bivariate portfolio sorts based on operating profit are positively associated with the expected stock return and are also statistically significant.

Hou et al. (2020) show that among the 462 anomalies found, the firm's profitability is still robust to explain abnormal returns. Different profitability measures gross profits, operating profits, and return on equity are robust as anomalies in U.S. stock markets.

\section{Other Factors Affecting Expected Stock Return}

Capital Asset Pricing Model (CAPM) explained the association between risk and expected return on capital assets. CAPM is assumed that there is only one systematic risk, which is beta. According to CAPM, a market beta defined as a slope of market return in the market model has a positive linear relationship and can explain the cross-sectional expected stock return. However, since Banz (1981) found an anomaly of the firm size, so many anomalies have been identified that contradict the idea of the CAPM empirically. The anomalies suggest that there are other variables that can explain return better than CAPM. 
Firm size anomaly indicates that small firm has higher returns than big firms. Firms with a lower book-to-market equity ratio have greater stock returns than firms with higher bookto-market equity ratios.

Based on the anomalies founded during the 1980s, Fama \& French (1992) show that the majority of the anomalies can be captured by two main anomalies: the size of the firm and the market-to-book ratio of the firm the equity. Fama \& French (1993) based on the Fama \& French (1992) argument capital asset pricing model by establishing a three-factor model. In the three-factor model. They define two additional risk factors based on the size of the firm and book-to-market ratio anomalies. Even if they also show that other anomalies identified during the 1980s can be absorbed in these two risk factors, SMB (small minus big) and HML (high minus low).

For example, Novy-Marx (2013) argues that the three-factor model from Fama-French (1993) is not complete for accounting for expected stock return since it neglects the profitability and investment policy that rise the power of explanation of variations of the cross-sectional stock return. Titman et al. (2013). empirically, that investment is negatively associated with the expected stock return. Watanabe et al. (2013) confirm that profitability is associated positively with expected stock return. Fama \& French (2015) propose a fivefactor model by incorporating profitability and investment anomalies in their model. Empirically, Fama \& French's (2015) five-factor model performs better than three factors model in accounting for the cross-sectional expected stock return on portfolio sorted in the U.S. stock market. However, so many different asset pricing models are competing at the empirical level, as shown in Fama \& French (2016), Barillas \& Shanken (2017), and Stambaugh \& Yuan (2017). In argumentation of asset pricing model profitability still is concerned as one of the significant anomalies related with many anomalies (Stambaugh \& Yuan, 2017).

\section{Hypothesis Formulation}

A firm that shows historically and currently profitable is assumed to have huge potential of growth in profitability in the future. Akbas et al. (2017) argue that a positive association between the profitability of the firm and future stock returns comes from the profitability of the trend since the firm's profitability trend represents the firm's competitiveness in the current environment. In comparison, Stambaugh \& Yuan (2017) claim that the firm's profitability reflects several mispricing factors such as momentum. Yet He \& Narayanamoorthy (2020) argue that the firm's profitability is associated with earnings acceleration which market neglect that causes abnormal returns. On the other hand, Fama \& French (2015) categorize the firm's profitability as risk factors and incorporate the firm's profitability in their five factors model as one of the risk factors. Fama \& French (2018) incorporate momentum factors in their asset pricing model but still allow the firm's profitability as a risk factor. On the other hand, Bouchaud et al. (2019) relate the profitability anomalies with the investors' sticky expectations that are too slow to adjust the profitrelated information.

Based on the theories and previous research explained above, there are three proxies of firm profitability that positively affect expected stock return. Several studies conclude that firms with higher ROE have a higher expected stock return (Hou et al., 2015, 2016). On the other hand, there are several studies supporting that firms with higher gross profit earn a higher expected stock return. Gross profit scaled by book assets is the most accurate measure of true economic profitability (Novy-Marx, 2013; Akbas et al., 2017; Cakici et al., 
2021). According to Ball et al. $(2015,2016)$ and Berggrun et al. (2020), Hou et al. (2020), operating profit is a more comprehensive proxy of firm profitability. In formulating this hypothesis, since there is no general conclusion about the best proxy of firm profitability, we hypotheses as follows:

\section{$H_{1}$ : Firm profitability has a positive effect on expected stock return.}

\section{METHOD, DATA, AND ANALYSIS}

This study focuses on the non-financial firms in ASEAN because the profitability of the financial firms has quite different in its estimations. Thus, the population of this study consists of ASEAN countries' non-financial firms over the period of January 2010 to December 2019. The criteria used in the sampling process of this study are the availability of firms' financial data from January 2010 to December 2019; and includes only firms listed on the Indonesia Stock Exchange (IDX), The Stock Exchange of Thailand (SET), The Stock Exchange of Malaysia Berhad (KLSE), The Philippine Stock Exchange (PSE), and Ho Chi Minh City Stock Exchange (HOSE).

Firms' financial statements of each country can be obtained from the S\&P Market Intelligence database in the currency of the U.S. dollar. Moreover, the risk-free rate data from each country can be accessed on the Bloomberg Terminal database. Indonesia Government Bond Generic Bid Yield 1 Year (GIDN1YR Index), Thailand Government Bond 2 Year (GTTHB2YR Corp), Malaysia Government Bond 3 Year Yield (MAGY3YR Index), Philippines 91 Day T-Bill Auction Average Yield (PH91AVG Index), dan Vietnam Government Benchmark Bond 1 Year (GGVF1YR VNBF Index) serve as a proxy for the riskfree rate.

Even if Singapore, Myanmar, and Cambodia belong to the ASEAM, we exclude them. Singapore, we exclude because she is not a developing country. Myanmar and Cambodia are excluded for the relatively short history of the stock market. After collecting the data and eliminating the firms that do not have complete data, this study uses time-series data, with 121,200 observations, using the total sample of 1,010 firms from five countries. The number of firms used in each country is as follows: 128 Indonesian firms, 275 Thai firms, 444 Malaysian firms, 98 Philippines firms, and 65 Vietnamese firms.

\section{Empirical Model and Research Method}

Fama \& French's (1993) three-factor model and Fama-MacBeth's (1973) regression are used in this study to investigate the effect of firm profitability on expected stock return.

\section{Fama \& French (1993) Three-Factor Model}

By following Fama \& French's (1993) three-factor model, the empirical model of this study is as following equation 2 .

$$
\begin{array}{ll}
\left(R_{p}-R_{f}\right)_{t}=a_{0} & +\beta_{1}\left(R_{m}-R_{f}\right)_{t}+\beta_{2} S M B_{t}+\beta_{3} H M L_{t}+\varepsilon_{i, t} \\
\left(R_{p}-R_{f}\right)_{t} & =\text { Expected Excess Portfolio Return } \\
\left(\mathrm{R}_{\mathrm{m}}-\mathrm{R}_{\mathrm{f}}\right)_{\mathrm{t}} & =\text { Excess Market Return } \\
\mathrm{SMB} & =\text { Size Premium Risk Factor (Small minus Big) } \\
\mathrm{HML} & =\text { Value Premium Risk Factor (High minus Low) }
\end{array}
$$




$$
\varepsilon_{\mathrm{i}, \mathrm{t}} \quad=\text { Error term }
$$

Stocks are sorted yearly into ten portfolios from P1 (low) to P10 (high) based on operating profit-to-equity and operating profit-to-assets using percentiles To make ten different portfolios. Portfolios include average excess monthly return from January 2010 to December 2019. Excess market return, SMB, and HML can be obtained from the FamaFrench Emerging 5 Factors database, which consists of 26 emerging market countries.

\section{Fama-MacBeth (1973) Regression}

Firms with higher operating profit have a higher expected stock return (Ball et al., 2015; Berggrun et al., 2020). The empirical model based on Fama-MacBeth (1973) used in this study is as following equations 3 and 4 .

$$
\begin{array}{ll}
\left(R_{i}-R_{f}\right)_{t}=a_{0}+\beta_{1} O P / B E_{i, t}+\beta_{2} M E_{i, t}+\beta_{3} B / M_{i, t}+\beta_{4} M O M_{i, t}+\varepsilon_{i, t} \\
\left(R_{i}-R_{f}\right)_{t}=a_{0}+\beta_{1} O P / B A_{i, t}+\beta_{2} M E_{i, t}+\beta_{3} B / M_{i, t}+\beta_{4} M O M_{i, t}+\varepsilon_{i, t} \\
\left(\mathrm{R}_{\mathrm{i}}-\mathrm{R}_{\mathrm{f}}\right)_{\mathrm{t}} & =\text { Expected Excess Stock Return } \\
\mathrm{OP} / \mathrm{BE} & =\text { Operating Profit-to-Equity } \\
\mathrm{OP} / \mathrm{BA} & =\text { Operating Profit-to-Assets } \\
\mathrm{ME} & =\text { Market Value of Equity } \\
\mathrm{B} / \mathrm{M} & =\text { Book-to-Market Equity } \\
\mathrm{MOM} & =\text { Momentum } \\
\varepsilon_{\mathrm{i}, \mathrm{t}} & =\text { Error term }
\end{array}
$$

\begin{tabular}{|c|c|}
\hline Variables & Variables Operationalization \\
\hline Expected Excess Stock Return & $\left(R_{i}-R_{f}\right)=$ return individual stock - risk free rate \\
\hline Operating Profit-to-Equity & $\frac{O P}{R E}=\frac{\text { gross profit }-S G A \text { expense }- \text { interest expense }}{\text { h }}$ \\
\hline Operating Profit-to-Assets & $\frac{O P}{B A}=\frac{\text { gross profit }- \text { SGA expense }- \text { interest expense }}{\text { book value of assets }}$ \\
\hline Market Value of Equity & $M E=\ln ($ no. of shares outstanding $x$ market price $)$ \\
\hline Book-to-Market Equity & $\left.B / M=\ln \frac{\text { book value per share }}{\text { market value per share }}\right)$ \\
\hline Momentum & $\begin{array}{c}\text { MOM }=\left(R_{i}-R_{f}\right)_{t-6}+\left(R_{i}-R_{f}\right)_{t-5}+\left(R_{i}-R_{f}\right)_{t-4} \\
+\left(R_{i}-R_{f}\right)_{t-3}+\left(R_{i}-R_{f}\right)_{t-2}\end{array}$ \\
\hline
\end{tabular}

Table 1. Operationalization of Variables

From the existing econometric procedures, autocorrelation problems in Fama-French 3 Factors model are remedied using robust standard errors. Meanwhile, heteroscedasticity problem in Fama-MacBeth (1973) regression can be solved by Newey-West Standard Error. 


\section{RESULTS}

\section{Empirical Results}

Descriptive Statistics

Table 2. Descriptive Statistics

\begin{tabular}{lcccr}
\hline \multicolumn{1}{c}{ Variable } & Mean & $\begin{array}{c}\text { Standard } \\
\text { Deviation }\end{array}$ & Minimum & Maximum \\
\hline Expected Excess Stock Return & 0.0036 & 0.1118 & -0.2709 & 0.4495 \\
Operating Profit-to-Equity & 0.0848 & 0.1451 & -0.3913 & 0.5627 \\
Operating Profit-to-Assets & 0.0506 & 0.0802 & -0.1612 & 0.3220 \\
Market Value of Equity & 4.3913 & 1.7018 & 1.2648 & 9.0713 \\
Book-to-Market Equity & 0.0373 & 0.7211 & -1.6908 & 1.7235 \\
Momentum & 0.0301 & 0.2697 & -0.5657 & 1.0780 \\
\hline
\end{tabular}

Expected Excess Stock Return is measured by the individual monthly stock return minus the risk-free rate. Operating Profit-to-Equity is the ratio of operating profit (gross profit minus SGA expense and interest expenses) to book value of equity. Operating Profit-to-Assets is the ratio of operating profit (gross profit minus SGA expense and interest expenses) to the same yearbook value of assets. Market Value of Equity is the natural logarithm of the number of shares outstanding multiplied by the stock's market price. Book-to-Market Equity is the ratio of book value per share to the market value per share. Momentum is the cumulative excess stock return during five months from $\mathrm{t}-6$ to $\mathrm{t}-2$.

Source: Own processed data

Before running the regression for the entire sample data, a winsorization procedure is performed to eliminate the $1 \%$ highest and $1 \%$ lowest values for certain variables that are suspected of having outliers due to errors in the data collection process. We winsorize $1 \%$ extreme value to reduce bias from the extreme value of the variables that may produce inaccurate estimates due to the outliers in the data. Table 2 shows the result of descriptive statistics, which provide a general description of the sample data from January 2010 to December 2019.

Fama French (1993) Three-Factor Model

Table 3. Operating Profit-to-Equity Portfolio

\begin{tabular}{ccccccc}
\hline Portfolio & $\begin{array}{c}\text { Average } \\
\text { Return }\end{array}$ & Intercept & $(\boldsymbol{R} m-\mathbf{R} f)$ & SMB & HML & F-test \\
\hline P1 & -0.0013 & -0.0056 & $0.0092^{* * *}$ & $0.0047^{*}$ & 0.0002 & $43.75^{* * *}$ \\
$($ Low $)$ & & $(0.121)$ & $(0.000)$ & $(0.083)$ & $(0.935)$ & \\
& & & & & & \\
P2 & 0.0022 & -0.0015 & $0.0081^{* * *}$ & $0.0049^{* *}$ & 0.0000 & $49.99^{* * *}$ \\
& & $(0.618)$ & $(0.000)$ & $(0.028)$ & $(0.992)$ & \\
P3 & 0.0015 & -0.0022 & $0.0074^{* * *}$ & $0.0041^{* *}$ & 0.0018 & $56.25^{* * *}$ \\
& & $(0.402)$ & $(0.000)$ & $(0.041)$ & $(0.304)$ & \\
P4 & 0.0028 & -0.0005 & $0.0072^{* * *}$ & $0.0043^{* *}$ & 0.0003 & $64.19^{* * *}$ \\
& & $(0.815)$ & $(0.000)$ & $(0.014)$ & $(0.837)$ & \\
\hline
\end{tabular}




\begin{tabular}{cllllll}
\hline Portfolio & $\begin{array}{c}\text { Average } \\
\text { Return }\end{array}$ & Intercept & $($ Rm-Rf) & SMB & HML & F-test \\
\hline P5 & 0.0049 & 0.0013 & $0.0084^{* * *}$ & $0.0055^{* * *}$ & -0.0019 & $61.99^{* * *}$ \\
\hline P6 & 0.0077 & 0.0043 & $0.0079^{* * *}$ & $0.0068^{* * *}$ & -0.0006 & $52.64^{* * *}$ \\
& & $(0.620)$ & $(0.000)$ & $(0.082)$ & $(0.288)$ & \\
P7 & 0.0079 & 0.0046 & $0.0074^{* * *}$ & $0.0041^{* *}$ & -0.0006 & $71.59^{* * *}$ \\
& & $(0.104)$ & $(0.000)$ & $(0.017)$ & $(0.691)$ & \\
P8 & 0.0126 & $0.0093^{* * *}$ & $0.0075^{* * *}$ & $0.0060^{* * *}$ & -0.0010 & $51.23^{* * *}$ \\
& & $(0.000)$ & $(0.000)$ & $(0.003)$ & $(0.571)$ & \\
P9 & 0.0122 & $0.0085^{* *}$ & $0.0079^{* * *}$ & $0.0060^{* * *}$ & 0.0000 & $62.30^{* * *}$ \\
& & $(0.011)$ & $(0.000)$ & $(0.002)$ & $(0.999)$ & \\
P10 (High) & 0.0149 & $0.0115^{* * *}$ & $0.0079^{* * *}$ & $0.0054^{* *}$ & -0.0002 & $48.50^{* * *}$ \\
& & $(0.003)$ & $(0.000)$ & $(0.014)$ & $(0.908)$ & \\
\hline High-Low & 0.0162 & $0.0171^{* * *}$ & $-0.0013^{* *}$ & 0.0007 & -0.0004 & \\
& & $(0.000)$ & $(0.064)$ & $(0.608)$ & $(0.875)$ & \\
\hline
\end{tabular}

Expected Excess Portfolio Return is the value-weighted stock returns in the portfolio minus the risk-free rate. The average return is the descriptive statistic of average portfolio return from January 2010 to December 2019. Excess Market Return (Rm-Rf) is the market return of each exchange minus the risk-free rate (U.S. one-month T-Bill). SMB is the size premium factor is calculated as a difference of return portfolio of the weighted average of stock returns from small stocks minus return portfolio of a weighted average of stock returns of big stocks. HML is calculated as the difference between portfolio return of high book-to-market stock return minus low book-to-market ratio stock returns. Excess Market Return, SMB, and HML accessed through Fama/French Emerging 5 Factors database. ${ }^{*}=$ significant in $0.10, * *$ significant in $0.05,{ }^{* * *}=$ significant in 0.01 Source: Own processed data

Table 4. Operating Profit-to-Assets Portfolio

\begin{tabular}{ccclccc}
\hline Portfolio & $\begin{array}{c}\text { Average } \\
\text { Return }\end{array}$ & Intercept & $($ Rm-Rf $)$ & SMB & HML & F-test \\
\hline P1 & -0.0009 & -0.0051 & $0.0091^{* * *}$ & $0.0046^{*}$ & 0.0001 & $44.81^{* * *}$ \\
& & $(0.147)$ & $(0.000)$ & $(0.083)$ & $(0.971)$ & \\
P2 & 0.0017 & -0.0021 & $0.0080^{* * *}$ & $0.0047^{* *}$ & 0.0004 & $47.69^{* * *}$ \\
& & $(0.487)$ & $(0.000)$ & $(0.040)$ & $(0.844)$ & \\
P3 & 0.0021 & -0.0019 & $0.0079^{* * *}$ & $0.0053^{* *}$ & 0.0021 & $59.70^{* * *}$ \\
& & $(0.494)$ & $(0.000)$ & $(0.011)$ & $(0.232)$ & \\
P4 & 0.0027 & -0.0007 & $0.0075^{* * *}$ & $0.0051^{* * *}$ & -0.0003 & $55.77^{* * *}$ \\
\hline
\end{tabular}




\begin{tabular}{|c|c|c|c|c|c|c|}
\hline Portfolio & $\begin{array}{l}\text { Average } \\
\text { Return }\end{array}$ & Intercept & $(R m-R f)$ & SMB & HML & F-test \\
\hline & & $(0.785)$ & $(0.000)$ & $(0.009)$ & $(0.837)$ & \\
\hline \multirow[t]{2}{*}{ P5 } & 0.0056 & 0.0023 & $0.0079^{* * *}$ & $0.0035^{*}$ & -0.0026 & $53.72^{* * *}$ \\
\hline & & $(0.390)$ & $(0.000)$ & $(0.082)$ & $(0.148)$ & \\
\hline \multirow[t]{2}{*}{ P6 } & 0.0108 & $0.0070^{* *}$ & $0.0085^{* * *}$ & $0.0087^{* * *}$ & 0.0000 & $54.30^{* * *}$ \\
\hline & & $(0.017)$ & $(0.000)$ & $(0.000)$ & $(0.980)$ & \\
\hline \multirow[t]{2}{*}{ P7 } & 0.0084 & 0.0050 & $0.0078^{* * *}$ & $0.0046^{* *}$ & -0.0010 & $64.73^{* * *}$ \\
\hline & & $(0.118)$ & $(0.000)$ & $(0.013)$ & $(0.532)$ & \\
\hline \multirow[t]{2}{*}{ P8 } & 0.0110 & $0.0077^{* *}$ & $0.0076^{* * *}$ & $0.0043^{* *}$ & -0.0011 & $58.79^{* * *}$ \\
\hline & & $(0.019)$ & $(0.000)$ & $(0.022)$ & $(0.524)$ & \\
\hline \multirow[t]{2}{*}{ P9 } & 0.0110 & $0.0078^{* *}$ & $0.0069^{* * *}$ & $0.0055^{* * *}$ & 0.0008 & $51.59^{* * *}$ \\
\hline & & $(0.021)$ & $(0.000)$ & $(0.004)$ & $(0.646)$ & \\
\hline \multirow[t]{2}{*}{ P10 (High) } & 0.0125 & $0.0092^{* * *}$ & $0.0075^{* * *}$ & $0.0057^{* *}$ & -0.0003 & $56.04^{* * *}$ \\
\hline & & $(0.000)$ & $(0.000)$ & $(0.003)$ & $(0.858)$ & \\
\hline \multirow[t]{2}{*}{ High-Low } & 0.0134 & $0.0143^{* * *}$ & $-0.0016^{* *}$ & 0.0011 & -0.0004 & \\
\hline & & $(0.000)$ & $(0.010)$ & $(0.476)$ & $(0.975)$ & \\
\hline
\end{tabular}

Expected Excess Portfolio Return is the value-weighted stock returns in the portfolio minus the risk-free rate. The average return is the descriptive statistic of average portfolio return from January 2010 to December 2019. Excess Market Return (Rm-Rf) is the market return of each exchange minus the risk-free rate (U.S. one-month T-Bill). SMB is the size premium factor is calculated as a difference of return portfolio of the weighted average of stock returns from small stocks minus return portfolio of a weighted average of stock returns of big stocks. HML is calculated as the difference between portfolio return of high book-to-market stock return minus that of low book-to-market ratio stock returns. Excess Market Return, SMB, and HML accessed through Fama/French Emerging 5 Factors database. ${ }^{*}=$ significant in $0.10,{ }^{* *}=$ significant in $0.05,{ }^{* * *}=$ significant in 0.01

Source: Own processed data

Tables 3 and 4 are the estimated results of three-factor model portfolios based on operating profit-to-equity and operating profit-to-assets. Abnormal return that is represented in intercept monotonically ascends in with the increase of profitability of the portfolio. In Table 3, a portfolio with low profitability (P1) has -0.0013 as an abnormal return. In comparison, the portfolio in the middle range portfolio (P5) has 0.0049 as an abnormal return. Yet portfolio in high profitability (P10) has 0.0149 as an abnormal return. Even if the profitability of the portfolio increases, the abnormal return of the portfolio increases monotonically but is statistically insignificant. It is also shown a difference in abnormal return between P10 (high profitability) and P1 (low profitability) is not statistically different. Then based on this Fama-French 3 Factors model, we just said an increase of profitability of portfolio tends to increase the abnormal return, but statistically is not significant. 
Fama-MacBeth (1973) Regression

Table 5. Fama-MacBeth (1973) Operating Profit-to-Equity

\begin{tabular}{|c|c|c|c|c|}
\hline $\begin{array}{l}\text { Expected Excess Stock } \\
\text { Return }\end{array}$ & [1] & [2] & [3] & [4] \\
\hline Intercept & $\begin{array}{l}0.0000 \\
(0.924)\end{array}$ & $\begin{array}{l}-0.0058^{* * *} \\
(0.000)\end{array}$ & $\begin{array}{l}0.0024^{\star * *} \\
(0.000)\end{array}$ & $\begin{array}{l}0.0100^{* * *} \\
(0.000)\end{array}$ \\
\hline $\begin{array}{l}\text { Operating Profit-to- } \\
\text { Equity }\end{array}$ & $\begin{array}{l}0.0415^{\star * *} \\
(0.000)\end{array}$ & $\begin{array}{l}0.0366^{* * *} \\
(0.000)\end{array}$ & $\begin{array}{l}0.0196^{* * *} \\
(0.000)\end{array}$ & $\begin{array}{l}0.0228^{* * *} \\
(0.000)\end{array}$ \\
\hline Market Value of Equity & & $\begin{array}{l}0.0014^{* * *} \\
(0.000)\end{array}$ & & $\begin{array}{l}-0.0017^{* * *} \\
(0.000)\end{array}$ \\
\hline Book-to-Market Equity & & & $\begin{array}{l}-0.0139^{* * *} \\
(0.000)\end{array}$ & $\begin{array}{l}-0.0160 * \\
(0.000)\end{array}$ \\
\hline Momentum & & & & $\begin{array}{l}-0.0027^{* * *} \\
(0.79)\end{array}$ \\
\hline F-test & $289.34^{* * *}$ & $179.45^{* * *}$ & $587.19^{* * *}$ & $304.46^{* * *}$ \\
\hline
\end{tabular}

Expected Excess Stock Return is the individual monthly stock return minus the risk-free rate. Operating Profitto-Equity is the ratio of operating profit (gross profit minus SGA expense and interest expenses) to book value of equity. Operating Profit-to-Assets is the ratio of operating profit (gross profit minus SGA expense and interest expenses) to the book value of assets. Market Value of Equity is the natural logarithm of the number of shares outstanding multiplied by the market price. Book-to-Market Equity is the ratio of the natural logarithm of book value per share to the market value per share. Momentum is the cumulative excess stock return during five months from $\mathrm{t}-6$ to $\mathrm{t}-2 .^{*}=$ significant in $0.10,{ }^{* *}=$ significant in $0.05,{ }^{* * *}=$ significant in 0.01

Source: Own processed data

Table 6. Fama-MacBeth (1973) Operating Profit-to-Assets

\begin{tabular}{lllll}
\hline $\begin{array}{l}\text { Expected Excess Stock } \\
\text { Return }\end{array}$ & {$[1]$} & [2] & {$[3]$} & {$[4]$} \\
\hline Intercept & 0.0000 & $-0.0065^{* * *}$ & $0.0025^{* * *}$ & $0.0095^{* * *}$ \\
& $(0.881)$ & $(0.000)$ & $(0.000)$ & $(0.000)$ \\
& & & & \\
$\begin{array}{l}\text { Operating Profit-to- } \\
\text { Assets }\end{array}$ & $0.0714^{* * *}$ & $0.0628^{* * *}$ & $0.0302^{* * *}$ & $0.0339^{* * *}$ \\
& $(0.000)$ & $(0.000)$ & $(0.000)$ & $(0.000)$ \\
\hline
\end{tabular}




\begin{tabular}{|c|c|c|c|c|}
\hline $\begin{array}{l}\text { Expected Excess Stock } \\
\text { Return }\end{array}$ & [1] & [2] & [3] & [4] \\
\hline \multirow[t]{2}{*}{ Market Value of Equity } & & $0.0016^{* * *}$ & & $-0.0016^{* * *}$ \\
\hline & & $(0.000)$ & & $(0.000)$ \\
\hline \multirow[t]{2}{*}{ Book-to-Market Equity } & & & $-0.0140^{* * *}$ & $-0.0160^{*}$ \\
\hline & & & $(0.000)$ & $(0.000)$ \\
\hline \multirow[t]{2}{*}{ Momentum } & & & & $-0.0025^{* * *}$ \\
\hline & & & & $(0.000)$ \\
\hline F-test & $288.36^{* * *}$ & $182.86^{* * *}$ & $584.83^{* * *}$ & $301.54^{* * *}$ \\
\hline
\end{tabular}

Expected Excess Stock Return is the individual monthly stock return minus the risk-free rate. Operating Profitto-Equity is the ratio of operating profit (gross profit minus SGA expense and interest expenses) to book value of equity. Operating Profit-to-Assets is the ratio of operating profit (gross profit minus SGA expense and interest expenses) to the book value of assets. Market Value of Equity is the natural logarithm of the number of shares outstanding multiplied by the market price. Book-to-Market Equity is the ratio of the natural logarithm of book value per share to the market value per share. Momentum is the cumulative excess stock return during five months from $\mathrm{t}-6$ to $\mathrm{t}-2 .^{*}=$ significant in $0.10,{ }^{* *}=$ significant in $0.05,{ }^{* * *}=$ significant in 0.01

Source: Own processed data

Tables 5 and 6 show the Fama-MacBeth (1973) regression result based on operating profit-to-equity and operating profit-to-assets. Column 1 tested the univariate power of profitability (operating profit-to-equity and operating profit to-assets) and expected stock return. Based on the estimated results, we find that a positive and significant association between the profitability of the firm and expected stock return. The positive and significant association between the profitability of the firm and expected stock return can be interpreted as the more profitable firms, the higher expected stock return. Our findings reconfirm the result of Ball et al. (2015, 2016), Berggrun et al. (2020), and Cakici et al. (2021). Column 2 tests the bivariate power between profitability (operating profit-to-equity and operating profit to-assets) and market value of equity to predict expected stock return. Both variables show a positive and significant effect on expected stock return. Column 3 tests whether profitability (operating profit-to-equity and operating profit to-assets) and bookto-market equity have predictive ability to expected stock return. The result of this study indicates that profitability has a positive effect, while book-to-market equity is negatively related to expected stock return. Furthermore, column 4 tests the effect of profitability (operating profit-to-equity and operating profit to-assets), the market value of equity, bookto-market equity, and momentum on expected stock return. Profitability scaled by operating profit-to-equity or operating profit-to-assets has a positive and significant effect, while the control variables have a negative and significant effect on expected stock return. Column 4 in Table 6 shows that the coefficient of variable profitability has 0.0339 and is significant at a $1 \%$ significant level. In other words, if the profitability of the increase is one percent, the expected return of the stock increase by $3.39 \%$. 
The market value of equity has a negative effect on return when all independent variables are tested simultaneously. As mentioned before, this finding indicates that firms with a low market value of equity have significantly higher expected stock returns.

\section{CONCLUSION, LIMITATIONS, AND SUGGESTIONS}

This study aims to analyze the effect of firm profitability on expected stock return in the ASEAN stock market in the period January 2010 to December 2019. This study uses sample data from five countries in ASEAN stock markets: Indonesia, Thailand, Malaysia, Filipina, and dan Vietnam, with 121,200 total observations from 1,010 firms. The main result of this study is that there is a positive and significant relationship between profitability scaled by operating profit-to-equity or operating profit-to-assets and expected stock return in the ASEAN stock market. This indicates that more profitable firms will result in higher expected stock returns. Furthermore, this study investigates the effects of the profitability of the firm to the portfolio return-based portfolio sorted by operating profit-to-equity and operating profit-to-assets using the Fama-French (1993) factors model. Due to research limitations, this study uses Fama/French Emerging 5 Factors database so that SMB and HML do not have predictive ability to explain expected stock return in the ASEAN stock market. Thus, our finding is contrary to the result found by Fama \& French (1993). However, this research only applies 3 factor model of Fama-French, which then needs to be expanded to include other anomalies. We use gross and operating profitability as proxies of profitability of the firm; however, other profitability measures also be used to reexamine the relationship between stock return and profitability of the firm.

\section{REFERENCES}

Akbas, F., Jiang, C., \& Koch, P. D. (2017). The trend in firm profitability and the cross-section of stock returns. Accounting Review, 92(5), 1-32. https:/ / doi.org/10.2308/accr-51708

Ball, R., Gerakos, J., Linnainmaa, J. T., \& Nikolaev, V. (2016). Accruals, cash flows, and operating profitability in the cross section of stock returns. Journal of Financial Economics, 121(1), 28-45. https:/ / doi.org/10.1016/j.jfineco.2016.03.002

Ball, R., Gerakos, J., Linnainmaa, J. T., \& Nikolaev, V. V. (2015). Deflating profitability. Journal of Financial Economics, 117(2), 225-248. https:// doi.org/10.1016/j.jfineco.2015.02.004

Banz, R. W. (1981). The relationship between return and market value of common stocks. Journal of Financial Economics, 9, 3-18. https:// doi.org/https:/ / doi.org/10.1016/0304405X(81)90018-0

Barillas, F., \& Shanken, J. (2017). Which alpha? Review of Financial Studies, 30(4), 1316-1338. https:// doi.org/10.1093/rfs/hhw101

Berggrun, L., Cardona, E., \& Lizarzaburu, E. (2020a). Firm profitability and expected stock returns: Evidence from Latin America. Research in International Business and Finance, 51(May 2019). https:// doi.org/10.1016/j.ribaf.2019.101119

Berggrun, L., Cardona, E., \& Lizarzaburu, E. (2020b). Firm profitability and expected stock returns: Evidence from Latin America. In Research in International Business and Finance (Vol. 51). https://doi.org/10.1016/j.ribaf.2019.101119 
Bouchaud, J. P., Krüger, P., Landier, A., \& Thesmar, D. (2019). Sticky Expectations and the Profitability Anomaly. Journal of Finance, 74(2), 639-674. https:// doi.org/10.1111/jofi.12734

Cakici, N., Chatterjee, S., Tang, Y., \& Tong, L. (2021). Alternative profitability measures and cross-section of expected stock returns: international evidence. Review of Quantitative Finance and Accounting, 56(1), 369-391. https://doi.org/10.1007/s11156-020-00897-7

Fama, E. F., \& French, K. R. (1992). The Cross-Section of Expected Stock Return. The Journal of Finance, 47(2), 427-465.

Fama, E. F., \& French, K. R. (1993). Common risk factors in the returns on stocks and bonds. Journal of Financial Economics, 33, 3-56. https:/ / doi.org/10.1016/0304-405X(93)900235

Fama, E. F., \& French, K. R. (2015). A five-factor asset pricing model. Journal of Financial Economics, 116(1), 1-22. https:/ / doi.org/10.1016/j.jfineco.2014.10.010

Fama, E. F., \& French, K. R. (2016). Dissecting Anomalies with a Five-Factor Model. Review of Financial Studies, 29(1), 69-103. https:/ / doi.org/10.1093/rfs/hhv043

Fama, E. F., \& French, K. R. (2018). Choosing factors. Journal of Financial Economics, 128(2), 234-252. https:// doi.org/10.1016/j.jfineco.2018.02.012

Fama, E. F., \& MacBeth, J. D. (1973). Risk, Return, and Equilibrium: Empirical Tests. The Journal of Political Economy, 81(3), 607-636. https:/ / doi.org/10.1086/260445

He, S., \& Narayanamoorthy, G. (Gans). (2020). Earnings acceleration and stock returns. Journal of Accounting and Economics, 69(1), 101238. https:// doi.org/10.1016/j.jacceco.2019.101238

Hou, K., Xue, C., \& Zhang, L. (2015). Digesting anomalies: An investment approach. Review of Financial Studies, 28(3), 650-705. https:/ / doi.org/10.1093/rfs/hhu068

Hou, K., Xue, C., \& Zhang, L. (2020). Replicating Anomalies. Review of Financial Studies, 33(5), 2019-2133. https://doi.org/10.1093/rfs/hhy131

Liu, D., \& Yadohisa, H. (2018). Capturing Profitability in Asset Pricing Models for Japanese Equities 1994-2016. International Journal of Economics and Finance, 10(5), 254. https://doi.org/10.5539/ijef.v10n5p254

Margaretha, F., \& Supartika, N. (2016). Factors Affecting Profitability of Small Medium Enterprises (SMEs) Firm Listed in Indonesia Stock Exchange. Journal of Economics, Business and Management, 4(2), 132-137. https://doi.org/10.7763/joebm.2016.v4.379

Modigliani, F., \& Miller, M. H. (1961). Dividend Policy, Growth, and the Valuation of Shares. The Journal Of Business, 34(4), 411-433.

Stambaugh, R. F., \& Yuan, Y. (2017). Mispricing factors. In Review of Financial Studies (Vol. 30, Issue 4). https:/ / doi.org/10.1093/rfs/hhw107

Titman, S., Wei, K. C. J., \& Xie, F. (2013). Market development and the asset growth effect: International evidence. Journal of Financial and Quantitative Analysis, 48(5), 1405-1432. https:/ / doi.org/10.1017/S0022109013000495 
Watanabe, A., Xu, Y., Yao, T., \& Yu, T. (2013). The asset growth effect: Insights from international equity markets. Journal of Financial Economics, 108(2), 529-563. https:// doi.org/10.1016/j.jfineco.2012.12.002

Yin, L., Wei, Y., \& Han, L. (2020). Firms' profit instability and the cross-section of stock returns: Evidence from China. Research in International Business and Finance, 53(February), 101203. https:// doi.org/10.1016/j.ribaf.2020.101203 